\title{
Risk Factors of Acute Respiratory Infections in Practice Area for Community of Medical Students in Semarang
}

\author{
Faktor Risiko Infeksi Saluran Pernapasan Akut di Wilayah Praktik \\ Komunitas Mahasiswa Kedokteran di Semarang
}

Siti Thomas Zulaikhah*, Purwito Soegeng*, Titiek Sumarawati**

\begin{abstract}
*Public Health Departement, Faculty of Medicine, Islam Sultan Agung University, Semarang, Indonesia, **Biomedic Departement, Faculty of Medicine, Islam Sultan Agung University, Semarang, Indonesia
\end{abstract}

\begin{abstract}
Acute respiratory infection (ARI) ranks first of 10 major diseases in Primary Health Care Bangetayu with the highest percentage in Penggaron Lor Subdistrict. Skill to learn distribution and frequency of diseases as well as determinant factors that affect human health is needed in determine the most effective intervention to increase public health level. This study aimed to determine dominant factors related to ARI incidence in location of practice for community of medical students of Islam Sultan Agung University, Semarang. This study used cross-sectional design with 100 respondents and the samples were collected by stratified random sampling. Ten variables examined were environmental sanitation risk factors, while six related to behavior and health care. Data analysis used a chi-square test (bivariate) and multiple regression logistic (multivariate). Environmental sanitation factors were significantly related to ARI including the presence of ventilation, smoke hole kitchen, bedroom, residential density and the most dominant factor was the habit of smoker family members in Penggaron Lor Subdistrict. This location can be used as a practice area for the community of medical students who take Public Health Studies due to complex health problems.
\end{abstract}

Keywords: Acute respiratory infection, behavior, environmental sanitation, health care

\begin{abstract}
Abstrak
Infeki saluran pernapasan akut (ISPA) menempati urutan pertama dari 10 besar penyakit di Puskesmas Bangetayu dengan persentase terbanyak di Kelurahan Penggaron Lor. Keterampilan untuk mempelajari distribusi dan frekuensi penyakit serta faktor determinan yang memengaruhi manusia sangat diperlukan untuk menetapkan intervensi yang paling efektif untuk meningkatkan derajat kesehatan masyarakat. Perlu dilakukan penelitian untuk mengetahui faktor risiko yang paling dominan berhubungan dengan kejadian ISPA di lokasi praktik komunitas mahasiswa Fakultas Kedokteran Universitas Islam Sultan Agung Semarang. Penelitian ini menggunakan desain potong lintang dengan jumlah responden 100 orang dan sampel dikumpulkan dengan menggunakan stratified random sampling. Sepuluh variabel yang diteliti adalah faktor risiko sanitasi lingkungan, sedangkan enam faktor risiko terkait dengan perilaku dan pelayanan kesehatan. Data dianalisis secara bivariat dengan uji kai kuadrat dan multivariat dengan regresi logistik ganda. Faktor yang berhubungan dengan kejadian ISPA adalah ventilasi, lubang asap dapur, ruang tidur, dan kepadatan hunian. Faktor yang paling dominan adalah kebiasaan anggota keluarga yang merokok di Kelurahan Penggaron Lor. Lokasi ini dapat digunakan sebagai lahan praktik komunitas bagi mahasiswa kedokteran yang sedang kepaniteraan di program studi IImu Kesehatan Masyarakat karena memiliki permasalahan kesehatan yang kompleks.
\end{abstract}

Kata kunci: Infeksi saluran pernapasan akut, perilaku, sanitasi lingkungan, pelayanan kesehatan

How to Cite: Zulaikhah ST, Soegeng P, Sumarawati T. Risk factors of acute respiratory infections in practice area for community of medical students in Semarang. Kesmas: National Public Health Journal. 2017; 11 (4): 192-197. (doi:10.21109/kesmas.v11i4.1281)
Correspondence: Siti Thomas Zulaikhah, Public Health Departement, Faculty of Medicine, Islam Sultan Agung University, Kaligawe Main Street KM 4, Semarang Indonesia 50112, Phone: +6224-6583584, e-mail: thomasanalis17@yahoo.co.id Received: November $29^{\text {th }} 2016$

Revised: February $8^{\text {th }} 2017$

Accepted: April $3^{\text {rd }} 2017$ 


\section{Introduction}

According to World Health Organization (WHO), the role of the doctor includes care provider, decision maker, educator, manager and community leader. One of the jobs that will be undertaken is that a health center is responsible for public health in the working area of around 30,000 residents. Study on the distribution and frequency of diseases as well as determinants that influence human is needed to set the most effective intervention to increase public health level. ${ }^{1}$ Diagnosis of community is developed to support doctor's competence areas, particularly the seventh area which concerns on health problem management. ${ }^{2}$ To gain experience in diagnosing health problems among society, the education of students who are undergoing medical profession in Public Health Studies are taking pleace in locations that have complex health problems. Penggaron Lor is one of the villages in Bangetayu Primary Health Care area where acute respiratory infection (ARI) ranks first during the last 10 years.

Transmission of ARI disease may occur through polluted air, source of diseases entering the body through respiratory passages, making ARI belongs to one of air borne disease. There are many theories on the cause of ARI, as stated by Blum in Notoatmodjo, ${ }^{3}$ there were four major factors affecting on health level, namely environment, behavior, health services and genetic.

Healthy environment is a conducive environment for the embodiment of healthy condition, which is pollutionfree environment, available hygienic water, adequate environment sanitation, healthy housing and settlement, health insight-based planning and social life helping one another. Environmental factor includes condition of settlement/housing, education, social economy, while behavior is reflected in daily life habit such as eating pattern, individual hygiene, lifestyle and behavior to health endeavors. ${ }^{4}$ Healthy condition of settlement/housing is one of media to reach optimum health level. To obtain healthy condition of house, availability of housing sanitation media including ventilation, temperature, humidity, residential density, natural lighting, building construction, waste disposal, feces disposal and provision of hygienic water are needed. ${ }^{5}$ According to study by Sulistyowati, ${ }^{5}$ in Trenggalek District in 2010, the proportion of pneumonia sufferer toddlers that had house ventilation which did not meet health requirements was $57.8 \%$. Statistical test results showed a significant relation between pneumonia incidence and ventilation ( $\mathrm{p}$ value $=0.042)$. Odds ratio $(\mathrm{OR})$ score 1.9 with $95 \%$ confidence interval $(\mathrm{CI}): 1.0-3.4$ means that toddlers who had house ventilation which did not meet health requirements were 1.9 times more likely to suffer from pneumonia. 6

Behavior of people should take an active role in maintaining and improving health for the embodiment of healthy behavior. Healthy behavior is proactive behavior to maintain and improve health, prevent from risks, for self-protection from disease threats, and to take an active role in public health movement. Study of Harianja, ${ }^{6}$ showed relation between the existence of smoker family members and incidence of Acute Upper Respiratory Tract Infection among toddlers with $\mathrm{p}$ value 0.001 . Prevalence ratio result of Acute Upper Respiratory Tract Infection incidence among toddlers who had smoker family members compared to toddlers who did not have smoker family members was 3.21 (95\% CI: 1.15 - 8.93), which means that existence of smoker among family members was the risk factor of Acute Upper Respiratory Tract Infection incidence. $^{6}$

WHO emphasizes that the key to improve health level and enable to reach healthy Indonesia is by improving primary health care (PHC). PHC provides easier access to get health care facilities, commitment to reach equalization in term of health care, public participation in building and implementing health agenda. The domains of Human Development Index (HDI) include the entire health, education, economy by implementing health prospectives, encouraging people to get healthy lifestyle, maintaining and improving health care quality as well as improving individual, family and public health including condition of their living environment. Public health care is public goods in aiming to maintain and improve health and to prevent from diseases without ignoring disease healing and health recovery. ${ }^{7}$ This study aimed to determine the most dominant factor related to ARI incidence in Penggaron Lor Subdistrict, Genuk District, Semarang City, so the area is appropriately used as the location of a field practice for medical students of Islam Sultan Agung University, Semarang.

\section{Method}

This study was an observational study with cross-sectional design. ARI as the dependent variable and the independent variables were environmental sanitation which includes feces disposal, hygiene water provision, waste disposal, wastewater disposal, ventilation, kitchen smoke hole, bedroom, yard clean and utilized as well as the presence of cages in the house. Other independent variables were smoker family members, the family awareness of nutrition, residential density, physical activity, handwashing, and not littering. The next independent variable health services which is based on indicators of functions of the clinic, which is the central driver of health-oriented development, community empowerment centers and health care centers strata. Health care was cathehorized good if the total score was greater than or equal to mean and bad if the total score was than less mean.

The study was conducted in Penggaron Lor Subdis- 
Table 1. Distribution of Characteristics Respondents

\begin{tabular}{llrc}
\hline Characteristics of Respondents & Category & n & Percentage \\
\hline \multirow{2}{*}{ Sex } & Male & 87 & $87 \%$ \\
Age & Female & 13 & $13 \%$ \\
& Mean & 41 & \\
& SD & 8 & \\
Minimum & 26 & \\
Education & Maximum & 56 & \\
& Not graduated from elementary school & 0 & 0 \\
& Graduated from elementary school & 12 & $12 \%$ \\
& Graduated from primary school & 34 & $34 \%$ \\
Employment & Graduated from high school & 47 & $47 \%$ \\
& College & 7 & $7 \%$ \\
& Labor & 36 & $36 \%$ \\
Family income/month & Trader & 29 & $29 \%$ \\
& Worker & 24 & $24 \%$ \\
& Teacher & 7 & $7 \%$ \\
& Civil servant & 4 & $4 \%$ \\
& $<2$ million & 58 & $58 \%$ \\
& $\geq 2$ million & 42 & $42 \%$ \\
\hline
\end{tabular}

Notes:

$\mathrm{n}=$ Number of Sample

trict in December 2012. The population in this study was all households in Penggaron Lor Subdistrict, amounting to 1,142 and was divided into 4 subvillage (rukun warga) and 25 neighborhood (rukun tetangga), minimum sample size of 100 households were taken with stratified random sampling. Respondent taken in one family was represented by one respondent, namely father or mother who met inclusion and exclusion criteria. Inclusion criteria in this study included father or mother living in Penggaron Lor at least three months, the age of respondents was between 20 - 50 years old, having writing and reading abilities and willing to be respondents. Exclusion criteria in this study included respondents at the time of data taking were absent, respondents had moved to another house and respondents did not fill questionnaire completely.

This study used primary data obtained from respondents through interviews and direct observation to the respondent's house with a structured questionnaire. Questionnaire to assess condition of house environment was arranged based on Technical Guidance to Assessment of Healthy House from Ministry of Health Republic of Indonesia in 2007 (a), questionnaire to assess hygienic and healthy lifestyle was arranged based on Hygienic and Healthy Lifestyle of household order from the Ministry of Health in 2007(b), and questionnaire to assess health care was arranged based on indicators of functions of primary health care. 8,9 ARI incidence was assessed by questioning whether respondents or family members who suffered from ARI disease within the last one month.

The collected data was analyzed univariate, bivariate and multivariately analyzes. Univariate analysis was conducted by calculating distribution of frequency and pro- portion to determine characteristics of study subjects. Bivariate analysis used chi square test because both independent and dependent variables were in form of categorical data. Multivariate analysis used multiple logistic regression, conducted as the follow-up of bivariate analysis by involving statistically significant variables ( $\mathrm{p}$ value $<0.05$ ) and variables that had value ( $p$ value $<0.25) .10$

\section{Results}

Table 1 describes the results based on univariate analysis, to obtain a frequency distribution characteristics of respondents that include sex, age, education, employment and mothly family income.

Table 2 shows the relation of independent and dependent variables. The relation was statistically significant ( $p$ value $\leq 0.05$ ) as seen from independent variables ventilation, kitchen smoke hole, bedroom, stockyard separated from house, smoking habit, nutrition conscious family, residential density, and physical activities/sport.

Table 3 shows the results of the multivariate analysis result of the existing variables to determine the most dominant factor related to ARI. Variable which can be included into multivariate model is variable which has $\mathrm{p}$ value $<0.25$ in bivariate analysis. Results of multivariate test found significant five variables ( $\mathrm{p}$ value $<0.05$ ). The most dominant risk factors were habit of smoker family members, unavailable kitchen smoke hole, unqualified ventilation, residential density and unqualified bedroom.

\section{Discussion}

Of the 10 environmental factors examined, only four significantly associated with the incidence of ARI, namely ventilation, kitchen smoke hole, bedroom, residential density and stockyard separated by house. Ventilation $\mathrm{p}$ 
Table 2. Bivariate Analysis of Independent Variable with Acute Respiratory Infection

\begin{tabular}{|c|c|c|c|c|c|c|}
\hline \multirow{2}{*}{ Variable } & \multirow{2}{*}{ Category } & \multicolumn{2}{|l|}{ ARI } & \multirow{2}{*}{ p Value } & \multirow{2}{*}{ PR } & \multirow{2}{*}{$\mathbf{9 5} \% \mathbf{C I}$} \\
\hline & & Yes $(\%)$ & No $(\%)$ & & & \\
\hline \multicolumn{7}{|l|}{ Environment sanitation } \\
\hline \multirow[t]{2}{*}{ Feces disposal } & Unqualified & $27(75)$ & $9(25)$ & 0.616 & 1.07 & $(0.83-1.37)$ \\
\hline & Qualified & $45(74.3)$ & $19(29.7)$ & & & \\
\hline \multirow[t]{2}{*}{ Hygienic water provision } & Unqualified & $21(60)$ & $14(40)$ & 0.051 & 0.76 & $(0.57-1.03)$ \\
\hline & Qualified & $51(78.5)$ & $14(21.5)$ & & & \\
\hline \multirow[t]{2}{*}{ Waste disposal } & Unqualified & $51(72.9)$ & $19(27.1)$ & 0.771 & 1.04 & $(0.79-1.37)$ \\
\hline & Qualified & $21(70)$ & $9(30)$ & & & \\
\hline \multirow[t]{2}{*}{ Wastewater disposal } & Unqualified & $43(71.7)$ & $17(28.3)$ & 0.928 & 0.99 & $(0.77-1.26)$ \\
\hline & Qualified & $29(72.5)$ & $11(27.5)$ & & & \\
\hline \multirow[t]{2}{*}{ Ventilation } & Unqualified & $58(79.5)$ & $15(20.5)$ & 0.006 & 1.53 & $(1.05-2.25)^{*}$ \\
\hline & Qualified & $14(51.9)$ & $13(48.1)$ & & & \\
\hline \multirow[t]{2}{*}{ Kitchen smoke hole } & Unavailable & $62(78.5)$ & $17(21.5)$ & 0.005 & 1.65 & $(1.04-2.92)^{*}$ \\
\hline & Available & $10(47.6)$ & $11(52.4)$ & & & \\
\hline \multirow{2}{*}{ Bedroom density } & Unqualified & $55(78.6)$ & $15(21.4)$ & 0.025 & 1.41 & $(1.39-1.94)^{*}$ \\
\hline & Qualified & $17(56.7)$ & $13(43.3)$ & & & \\
\hline \multirow{2}{*}{ Clean yard } & No & $39(69.6)$ & $17(30.4)$ & 0.554 & 1.08 & $(0.85-1.37)$ \\
\hline & Yes & $33(75)$ & $11(25)$ & & & \\
\hline \multirow{2}{*}{ Yard used } & No & $47(73.4)$ & $17(26.6)$ & 0.699 & 0.95 & $(0.73-1.23)$ \\
\hline & Yes & $25(69.4)$ & $11(30.6)$ & & & \\
\hline \multirow[t]{2}{*}{ Stockyard separated by house } & No & $28(58.3)$ & $20(41.7)$ & 0.003 & 1.45 & $(1.11-1.89)^{*}$ \\
\hline & Yes & $44(84.6)$ & $19(15.4)$ & & & \\
\hline \multicolumn{7}{|l|}{ Behavior } \\
\hline \multirow[t]{2}{*}{ Smoking habit } & Yes & $54(78.3)$ & $15(21.7)$ & 0.037 & 1.35 & $(1.09-1.86)^{*}$ \\
\hline & No & $18(58.1)$ & $13(41.9)$ & & & \\
\hline \multirow[t]{2}{*}{ Nutrition conscious family } & No & $14(51.9)$ & $15(48.1)$ & 0.006 & 1.53 & $(1.05-2.25)^{* *}$ \\
\hline & Yes & $58(79.5)$ & $13(20.5)$ & & & \\
\hline \multirow[t]{2}{*}{ Residential density } & Dense & $60(80)$ & $15(20)$ & 0.002 & 1.67 & $(1.09-2.55)^{*}$ \\
\hline & Not dense & $12(48)$ & $13(52)$ & & & \\
\hline \multirow[t]{2}{*}{ Physical activities/sport } & No & $50(64.1)$ & $28(35.9)$ & 0.001 & 1.56 & $(1.32-1.84)^{* *}$ \\
\hline & Yes & $22(100)$ & 0 & & & \\
\hline \multirow[t]{2}{*}{ Hand-washing habit } & No & $57(69.5)$ & $25(30.5)$ & 0.237 & 1.20 & $(0.93-1.54)$ \\
\hline & Yes & $15(83.3)$ & $3(16.7)$ & & & \\
\hline \multirow[t]{2}{*}{ Throwing waste arbitrarily } & Yes & $22(61.1)$ & $14(38.9)$ & 0.069 & 0.78 & $(0.59-1.85)$ \\
\hline & No & $50(78.1)$ & $14(21.9)$ & & & \\
\hline \multirow{2}{*}{ Health care service } & $\mathrm{Bad}$ & $13(46.4)$ & $15(53.6)$ & 0.061 & 0.76 & $(0.77-2.67)$ \\
\hline & Good & $59(81.9)$ & $13(18.1)$ & & & \\
\hline
\end{tabular}

Notes:

$\mathrm{PR}=$ Prevalence Ratio; $\mathrm{CI}=$ Confidence Interval

*Significant

value $\leq 0.05$ and $\mathrm{OR}=1.53$, it means respondents who had unqualified ventilation were 1.5 times more likely to suffer from ARI than respondents whose ventilations were qualified. This result was contrary to study of Wayangkau, ${ }^{11}$ who found no relation between ventilation and ARI among toddlers, but this result was in line with study by Yusuf and Sulistyowati. ${ }^{12}$ Qualified ventilation in accordance with Regulation of Ministry of Health Republic of Indonesia No. 1077/MenKes/Per/ V/2011 on Health Requirements of Housing are broad of ventilation minimum $10 \%$ of the whole floor broad. 13

Unqualified ventilation can cause proliferation of microorganisms that cause health problems in humans. ${ }^{13}$ Chronic obstructive pulmonary disease, lung cancer, low birth weight infant mortality, infant mortality age of less than one week, otitis media and ARI, tuberculosis often found in environments with indoor air quality is not good, the quality of indoor air is influenced by several
Table 3. Multivariate Analysis Results of Acute Respiratory Infection

\begin{tabular}{lcccc}
\hline Variable & $\boldsymbol{\beta}$ & $\mathbf{p}$ Value & $\mathbf{E x p}(\boldsymbol{\beta})$ & $\mathbf{9 5 \%} \mathbf{C I}$ \\
\hline Unavailable kitchen smoke hole & 2.13 & 0.010 & 8.36 & $2.17-40.80^{*}$ \\
Unqualified bedroom & 1.60 & 0.005 & 2.60 & $1.50-41.03^{*}$ \\
Smoking habit & 1.20 & 0.040 & 9.81 & $2.10-40.18^{*}$ \\
Dense residential density & 1.25 & 0.010 & 3.35 & $1.71-15.96^{*}$ \\
Unqualified ventilation & 5.12 & 0.001 & 6.90 & $5.10-69.60^{*}$ \\
\hline
\end{tabular}

Notes:

$\mathrm{CI}=$ Confidence Interval

factors, one of which is ventilation. ${ }^{13}$ Ventilation causes air circulation so the air can flow out and clean air from outside can enter into house. ${ }^{14}$

Available kitchen smoke hole with $\mathrm{PR}=1.6$, means that respondents who had unavailable kitchen smoke hole in their house were 1.6 times more likely to suffer from ARI than respondents who had available kitchen smoke holein their house. These results are in line with 
study by Wayangkau, ${ }^{11}$ stating that there was a relation between the incidence of kitchen smoke hole and ARI. Absence of kitchen smoke hole can worsen air quality in house. ${ }^{14}$

Unqualified bedroom density to have a PR $=1.4$ means that respondents who had unqualified bedroom density had risk of ARI 1.4 times compared to respondents who had qualified bedroom density. This study was not in line with Sunarsih, ${ }^{15}$ in which there was not significant association between bedroom density and ARI incidence among toddlers ( $\mathrm{p}$ value $=0.321$ ) Theoretically, bedroom density which is not fulfilled the health requirement will increase exposure from other risk factors like smoke cigarette from other smoker family members. ${ }^{15}$ The dense bedroom affects on lack of oxygen in the room, so the inhabitants decrease endurance, then rapid onset of respiratory illnesses such as respiratory infection. A small room will make breath shortness and easily catch the disease by other family members. According Keputusan Menteri Kesehatan Republik Indonesia 1999 spacious room to sleep at least $8 \mathrm{~m}^{2}$ and is not recommended more than two people. ${ }^{16}$

The existence of the cage in the house had PR $=1.45$ which means that respondent existence merges with the home cage had risk of ARI 1.45 times, compared to respondents who separate cage with the house. Cages not separated from the house will lead to the transmission of infectious diseases. Animals can become vectors of disease, and can transmit the disease to humans.

The existence of smoker family members would be at risk of ARI 1.35 times compared to the respondents and non-smoker family members. This result is contrary to study by Fahdiyani, et al, ${ }^{17}$ which stated that smoking behavior in women was not associated with ARI among infants $(p$ value $=0.097$ ). However, this result is linear with study by Salma stating that there was a relation between smoking in the house with ARI among infants ( $p$ value $=0.002$ ) and other study assert that if a family member smokes toddlers are at risk of ARI 2 times compared with non-smoker family members. ${ }^{18-20}$ Smoke (Environmental Tobacco Smoke/ETS) is a poisonous gas that is released from burning tobacco products usually contain Polycyclic Aromatic Hydrocarbons (PAHs) that are harmful to human health. ${ }^{13}$ Smoking can also cause pneumonia, respiratory system disorders, eye irritation, allergies, chronic bronchitis due to sulfur dioxide $\left(\mathrm{SO}_{2}\right)$, nitrogen dioxide $\left(\mathrm{NO}_{2}\right)$, carbon monoxide $(\mathrm{CO})$, carbon dioxide $\left(\mathrm{CO}_{2}\right)$.

Meanwhile, the family who is unaware of the nutritional balance had 1.5 times higher risk of ARI compared to families aware of nutrition. The result of this study is contrary to study by with Fahdiyani, et al, ${ }^{17}$ stating that the intake of vitamin A did not relate to ARI on infants. One contracted the disease easily to someone who does not consume a balanced nutrition is a infectious disease. Another study claim that there is a relation between nutritional status and the incidence of ARI on under-five children $(\mathrm{p}$ value $=0.029){ }^{21}$

High residential density was 1.6 times at risk of ARI exposure than less dense or unqualified residential. Resident density is the floor area of house divided by the number of the resident family member. Every person needs $9 \mathrm{~m}^{2}$ of space with calculation of the average ceiling height that is $2.80 \mathrm{~m}$. Resident density of house will increase room temperature caused by body heat excretion that will increase humidity due to water vapor from breathing. Therefore, the more number of house residents, the faster the air in the room contaminated by gas or bacteria. With many residents, oxygen level in the room decreases and followed by the increase of $\mathrm{CO}_{2}$ in the room and the effect of such increase is the decrease of air quality in the house. ${ }^{13}$

Not doing physical activities/sports was 1.5 times at risk of suffering from ARI than respondents who actively did sports. Results of Basic Health Study 2008 demonstrated that most population in Central Java did less physical activities (37\%). In Semarang City, respondents aged older than 10 years categorized as less physical activities was as much as $32.9 \%$. Physical activity was categorized 'sufficient' if the activities were performed continuously at least 10 minutes in an activity without stop and cumulatively 150 minutes within five days a week. ${ }^{22}$ Handwashing in this study did not relate to ARI as contrary to study of Luby, ${ }^{23}$ stating that handwashing with soap was effective to prevent ARI disease.

Risk factors significantly related to ARI incidence were ventilation, range hood, bedroom, presence of cage in home. Of the five factors, habit of smoker family member was the most dominant factor related to ARI.

\section{Conclusion}

Risk factors related to ARI in Penggaron Lor Subdistrict are ventilation, kitchen smoke hole, bedroom and presence of cage in home, habit of smoker family member, nutrition conscious family, residential density and physical activities/sports. Meanwhile, the predictive factors toward ARI incidence are range hood, bedroom, habit of smoker family member, residential density and ventilation. The most dominant predictive factor is the habit of smoker family member.

\section{Recommendation}

This study recommends the location as field practice area for medical students who perform clinical clerkship in department of public health and determine Penggaron Lor Subdistrict as development area of Faculty of Medicine Islam Sultan Agung University. This location may provide a good study experience in identifying any 
dynamic and complex public health problems, analyzing the roots of problems, explaining the reasons why the problems occur and giving alternative settlement of public health problems.

The alternative settlement of problems can be an intervention in the form of counseling, so public behavior toward health and environment sanitation can be better. The counseling should be provided to all people, especially men related to smoking habit. The counseling provides information about smoking dangers for health, dangers of being passive smokers, and effects of cigarette smoke for the people around. Moreover, this study recommends an approach to the subdistrict head to make policy regulating that the subdistrict is smoke free on Fridays, so later this area can be smoke-free area.

\section{Acknowledgment}

A sincere gratitude to Faculty of Medicine Islam Sultan Agung University that funded this study, Head of Bangetayu Primary Health Care, Penggaron Lor Subdistrict Head.

\section{References}

1. Hadisaputro S, Nizar M, Suwandono. Epidemiologi manajerial teori dan aplikasi. Semarang: Universitas Diponegoro; 2011.

2. Konsil Kedokteran Indonesia. Standar kompetensi dokter Indonesia. Jakarta: Konsil Kedokteran Indonesia; 2012.

3. Notoatmodjo S. Promosi kesehatan dan perilaku kesehatan. Jakarta: Rineka Cipta; 2012.

4. Departemen Kesehatan Republik Indonesia. Pedoman pemberantasan dan penatalaksanaan ISPA. Direktoral Jendral Kesehatan Masyarakat, Direktorat Promosi Kesehatan. Jakarta: Departemen Kesehatan Republik Indonesia; 2006.

5. Sulistyowati R. Hubungan antara rumah tangga sehat dengan kejadian pneumonia pada balita di Kabupaten Trenggalek [tesis]. Surakarta: Magister Kedokteran Keluarga Program Pascasarjana Universitas Sebelas Maret; 2010

6. Harianja E. Analisis beberapa faktor yang berhubungan dengan kejadian infeksi saluran pernafasan atas akut pada anak balita di Kelurahan Kemenangan Tani Kecamatan Medan Tuntungan [skripsi]. Medan: Universitas Sumatra Utara; 2010.

7. Trihono. Manajemen primary health care berbasis paradigma sehat. Jakarta: Sagung Seto; 2005.

8. Departemen Kesehatan Republik Indonesia. Pedoman teknis penilaian rumah sehat. Jakarta: Promosi Kesehatan Departemen Kesehatan Republik Indonesia; 2007.

9. Departemen Kesehatan Republik Indonesia. Perilaku hidup bersih dan sehat (PHBS) tatanan rumah tanggal. Jakarta: Promosi Kesehatan Departemen Kesehatan Republik Indonesia; 2007.

10. Dahlan MS. Pintu Gerbang mamahami statistik, metodologi dan epidemiologi. Jakarta: Sagung Seto; 2014.

11. Wayangkau EC, Wambrauw A, Simanjuntak TPT, The correlation of phsical of a house to the acute respiratory tract infection (ARTI) cases on toddler at Nendali Village, East Sentani District. International Journal of Study in Medical and Health Sciences. 2015; 5(4):1-7

12. Nur Achmad Yusuf \& Lilis Sulistyorini. Hubungan sanitasi rumah secara fisik dengan kejadian ISPA pada balita. Jurnal kesehatan Lingkungan. 2005; 1(2): 110-9.

13. Kementerian Kesehatan Republik Indonesia. Pedoman penyehatan udara dalam ruang rumah nomor 1077/Menkes/Per/V/2011. Jakarta: Kementerian Kesehatan Republik Indonesia. 2011.

14. Irianto K. Ilmu Kesehatan Masyarakat. Alfabeta: Bandung; 2014

15. Sunarsih E, Imelda G, Purba. Risk factor analysis of acute respiratory infection on children under five years old in Tanjung Pering Village Ogan Ilir. International Journal of Sciences (IJSBAR). 2015; 22(1).

16. Kementerian Kesehatan Republik Indonesia. Persyaratan Kesehatan Perumahan nomor 829/Menkes/SK/VII/1999. Jakarta: Departemen Kesehatan Republik Indonesia; 1999.

17. Fahdiyani R, Raksanagara AS, Sukandar H. Influence of household environment and maternal behaviors to upper respiratory infection among toddlers. Kesmas: National Public Health Journal. 2016; 10 (3): 120-6.

18. Salma M, Ismanto KY, Kallo KD. Hubungan kebiasaan merokok di dalam rumah dengan kejadian ispa pada anak umur 1-5 tahun di Primary Health Care Sario Kota Manado. E-journal Keperawatan (e-Kp). 2015; $3(2): 1-7$.

19. Ernawat, Farich. Hubungan faktor lingkungan rumah dengan faktor anak dengan kejadian ISPA pada anak balita di Desa Way Huwi primary health care Karanganyar Kecamatan Jati Agung Kabupaten Lampung Selatan tahun 2012 [Laporan Penelitian]. Available from: http.//ejournal.libang.depkes.go.id/index.php/MPK/download/2636/606.2012.

20. Mujiono, Anggraini. Studi tentang sanitasi rumah penderita ISPA di Desa Pakis Baru, Kecamatan Nawangan, Kabupaten Pacitan. Jurnal Penelitian Kesehatan Suara Forikes. 2011; 2(2).

21. Fatimah S. Faktor-faktor yang berkontribusi terhadap status gizi pada Balita di Kecamatan Ciawi Kabupaten Tasikmalaya [skripsi]. Bandung: Fakultas Ilmu Keperawatan Universitas Padjadjaran; 2008.

22. Departemen Kesehatan Republik Indonesia. Riset Kesehatan Dasar 2008 (online). 2009 [cited 2014 Oct 10]. Available from: http://www.depkes.go.id/downloads/materi_rakernas/panel5204/Balitb angkes.pdf

23. Luby SP, Agboatwalla M, Feikin DR, Painter J, Billhimer W, Altaf A, et al. Effect of handwashing on child health: a randomised controlled trial. Lancet Infectious Diseases. 2005; 366: 225-33. 